\title{
An Overlook at Bankruptcy Prediction in Italy in 2016: An Application of the Altman's Model on Failed Italian Manufacturing Companies In The 2016-First Quarter
}

\author{
Matteo Pozzoli \\ Dept. of Law, Parthenope University in Naples \\ Generale Parisi 13, Naples, 80133 \\ E-mail: matteo.pozzoli@uniparthenope.it \\ Francesco Paolone (Corresponding author) \\ Dept. of Law, Parthenope University in Naples \\ Generale Parisi 13, Naples, 80133 \\ E-mail: francesco.paolone@ uniparthenope.it
}

Received: October 10, 2016 Accepted: November 03, 2016 Published: November 27, 2016

doi:10.5296/ijafr.v6i2.10339 URL: http://dx.doi.org/10.5296/ijafr.v6i2.10339

\begin{abstract}
During their life cycle, businesses must face positive and negative phases in financial trends which translate into periods of success and failure, respectively. When a negative period shifts from temporary to permanent (and thus continues over time), the company is often destined to cease. This work aims to test the most used bankruptcy prediction model, the Altman Z-Score, through an application on a sample of Italian manufacturing companies (S.p.A. and S.r.l.) which went bankrupt within the first quarter of 2016. The results confirm a good predictive effectiveness in relation to bankrupted companies with significant discrepancies between the different, analyzed juridical entities. Further research is still open on Italian peculiarities that may require the development of ad hoc parameters.
\end{abstract}

Keywords: Altman's model, Bankruptcy prediction, Financial reporting, Financial accounting. 


\section{Introduction}

In today's global economic crisis, there are many attempts to find the best way to measure the prediction of corporate bankruptcy. Many scholars have provided a definition of "bankruptcy" over the past decades (Van Caillie, 1999; Daubie \& Meskens, 2002; Charitou et al., 2004) and models were based on the "financial distress" criterion (Beaver, 1966; Altman, 1968, 1977, 1984, 1993, 1995, 2005, 2006; Ohlson, 1980; Keasey and Watson, 1991; Hill et al., 1996; Doumpos \& Zopoudinis, 1999; Platt \&Platt, 2002) or on cash-flow insolvency (Laitinen, 1994), loan default (Ward \& Foster, 1997), capital reconstructions, informal government support and loan covenant renegotiations with banks (Taffler \& Agarwal, 2003).

A branch of international literature has focused on predicting bankruptcy using statistics and financial indicators. The pioneers date back to the 1930s (Smith, 1930; Ramser and Foster, 1931; Wall, 1936) when models were elaborated to help banks in making decisions on whether or not to approve credit requests. At the end of the 1960s, the adoption of univariate and multivariate statistical analysis has been provided and many scholars have focused on economic-financial indicators (Beaver, 1966; Altman, 1968). These studies have also been conducted by practitioners because of the simplicity of their application. ${ }^{\mathrm{i}}$

In spite of the vast research on failure prediction, the Z-Score Model introduced by Altman (1968) with its revisions $(1983 ; 1993 ; 1995 ; 2005)$ has been the dominant model applied all over the world. Therefore, although the Z-Score Model has been in existence for more than 45 years, it is still adopted, both in research and practice, as a main or supporting tool for financial distress prediction, especially within the Italian context (Altman et al., 2013).

The ratio of the mentioned model is still applicable, despite the heterogeneity of addressed enterprises and time, as it focuses upon the core elements that, allow enterprises to pursue their operations over time: financial stability and profitability.

This work focuses on the application of the most appropriate Z-Score model to Italian manufacturing companies (S.p.A. and S.r.l.) which declared bankruptcy in the first quarter of 2016. This work also intends to assess the effectiveness of the Revised Z-Score (Z' Score) (Altman, 1993) in predicting bankruptcy in the Italian manufacturing industries over the past years ${ }^{\text {ii }}$.

\section{Prior Literature}

\subsection{Financial Ratios Analysis}

As financial distress may lead to bankruptcy, early warning is extremely desirable, if not vital. Bankruptcy is defined as the inability of a business to repay its outstanding debt (Aliakbari, 2009). Aharony et al. (1980) pointed out that "An early warning signal of probable failure will enable both management and investors to take preventive measures [...]". Winakor and Smith (1935) found a remarkable difference between the measurement of financial ratios of unsuccessful companies as compared to the financially healthy ones. By using a framework similar to the model of gambling ruins, Beaver (1966) analysed individually a set of financial ratios for a sample of bankrupt firms, together with a sample of 
matching non-bankrupt firms. He found that the financial ratios of five years prior the bankruptcy have the ability to forecast the bankruptcy probability, and hence Beaver is considered to be the pioneer in constructing a bankruptcy prediction model. Therefore, the company is regarded as "reservoir of liquid assets, which is supplied by inflows and drained by outflows. [...]. The solvency of the firm can be defined in terms of the probability that the reservoir will be exhausted, at which point the firm will be unable to pay its obligations as they mature". With this statement, he meant that as long as there are cash reserves a company will survive.

\subsection{Insolvency Prediction Models}

Failure prediction models are relevant tools for bankers, investors, asset managers, rating agencies, and even for the distressed firms themselves. The international literature on corporate distress diagnosis has significantly increased over the past decades. Beaver (1966) used a univariate analysis and showed that five years prior to bankruptcy, insolvent companies presented a drop in sales revenues, a reduction of cash flows and income levels, and a huge growth of debts compared to healthy companies.

The first multivariate bankruptcy prediction model (Z-Score) was developed by E.I. Altman (1968) from New York University in $1968^{\mathrm{iii}}$. After this pioneering work, the multivariate approach to failure prediction spread worldwide among academics in accounting, finance, banking, and credit risk. The Z-Score model has become a prototype for many of these internal-rate based models.

Altman (1968) used a multivariate discriminant analysis (MDA) and found that financial indicators of healthy companies were different from those of insolvents. It also found that this diversity became progressively stronger as the date of bankruptcy approached. Since the first works of Beaver and Altman, the number of publications on business financial distress prediction has seen an exponential increase: there were more than 165 related models published in the English language (Bellovary et al., 2007).

A relevant contribution was made by Ohlson (1980) employing a logit regression to predict business bankruptcy by attempting to avoid several problems of the MDA approach. Extensions to Ohlson's technique include the development of industry-specific models (Platt et al., 1994) as well as the adoption of a multinomial logit approach to reduce misclassification errors by adding, a "weak" state of financial distress to the outcome space used to predict bankruptcy (Johnsen and Melicher, 1994). Keasey et al. (1990) investigated whether it is possible to discriminate simultaneously between healthy and failing firms for a number of reporting periods prior to failure, by applying multi-logit models. Lennox (1999) confirmed that the industry sector, company size and the economic cycle have substantial effects on the likelihood of business bankruptcy. Those kind of companies are expected to increase when the company in question is unprofitable, largely leveraged and free of liquidity problems.

More recent contributions provide support on financial ratios in predicting distress. According to $\mathrm{Wu}$ (2010), financial ratios can be categorized according to several aspects in 
order to measure the business performance or competence of a firm. For example, financial ratios can be used to measure a firm's profitability, liquidity, capital structure, and efficiency. Huang et al. (2008) confirm that financial ratios are relevant tools in prediction bankruptcy and are also commonly used to develop the models or classifiers. Altman et al. (2013) applied the Z-Score through an application to Italian companies subject to extraordinary administration between 2000 and 2010. The results confirm a good predictive effectiveness, though Italian peculiarities could require the development of ad hoc parameters. Since Beaver, Altman and Ohlson, the financial ratios have become a vital element of failure prediction methods.

More recent and valuable contributions on the efficacy of the above-mentioned models have been provided by Agarwal and Taffler (2008) and Bauer and Agarwal (2014), focusing on the performance of accounting-based models, market-based models and hazard models. These three types of models prevail in the accounting and finance literature. In accordance with Agarwal and Taffler (2008), there is little difference between accounting-based and marketbased models in the predictive accuracy so that the usage of accounting-based models allows for a higher level of risk-adjusted return on the credit activity. The third type (hazard models) that use either accounting and market information (Shumway, 1999; Campbell et al., 2006) were found to be superior in UK data in terms of bankruptcy prediction accuracy (their default probabilities were close to the observed default rates), ROC analysis, and information content (Bauer and Agarwal, 2014).

\section{The Z-Score model}

The Z-Score model has been modified several times over the past years by Altman (1977; 1983; 2002; et al., 1995) who has constantly revised the parameters and adapted the indices to different populations of companies other than American manufacturers quoted on the Stock Market. The Z'-Score (Altman, 1983) is an adaptation for private companies. The five indicators in the two Altman manufacturing firm versions (1968 and 1993) of the studies are listed in Table 1.

Table 1. Original and revised Z-Score $(1968,1993)$

\begin{tabular}{|l|l|l|l|}
\hline \multicolumn{2}{|l|}{ Original Z-Score (Altman, 1968, p. 603) } & \multicolumn{2}{l|}{ Z'Score (Altman, 1993, p. 122) } \\
\hline $\begin{array}{l}\text { Coefficie } \\
\text { nt }\end{array}$ & Ratio & $\begin{array}{l}\text { Coefficie } \\
\text { nt }\end{array}$ & Ratio \\
\hline 1.2 & Working Capital / Total Assets & 0.717 & Working Capital / Total Assets \\
\hline 1.4 & Retained Earnings / Total Assets & 0.847 & Retained Earnings / Total Assets \\
\hline 3.3 & $\begin{array}{l}\text { Operating Profit (EBIT) / Total } \\
\text { Assets }\end{array}$ & 3.107 & $\begin{array}{l}\text { Operating Profit (EBIT) / Total } \\
\text { Assets }\end{array}$ \\
\hline
\end{tabular}




\begin{tabular}{|l|l|l|l|}
\hline 0.60 & $\begin{array}{l}\text { Market Value Equity / Total } \\
\text { Liabilities }\end{array}$ & 0.420 & $\begin{array}{l}\text { Book Value Equity / Total } \\
\text { Liabilities }\end{array}$ \\
\hline 0.99 & Sales Revenues / Total Assets & 0.998 & Sales Revenues / Total Assets \\
\hline $\begin{array}{l}\text { Original-Z Score }=1.2 X_{1}+1.4 X_{2}+3.3 X_{3} \\
+0.60 X_{4}+0.99 X_{5}\end{array}$ & $\begin{array}{l}\text { Z'Score }=0.717 X_{1}+0.847 X_{2}+3.107 X_{3}+ \\
0.420 X_{4}+0.998 X_{5}\end{array}$ \\
\hline
\end{tabular}

Source: our elaboration

During the following years, parameters and coefficients were adapted for even more different situations, and another version of Altman's model was proposed in 1995 (Table 2). Altman, Hartzell and Peck (1995) developed the Z-Score for the non-manufacturing and manufacturing companies operating in developing countries for which they investigated a sample of Mexican companies. In the case of emerging markets, Altman, Hartzell and Peck proposed to add a constant $(+3.25)$ in order to standardize the results so that scores equal or less than 0 would be equivalent to the default situation (Altman, Danovi and Falini, 2013). Furthermore, the variables of the Z' Score were elaborated to be the same as the Z' Score, with the exclusion of the variable X5 (Sales Revenues/Total Assets), so as to filter the function from the possible distortion related to the sector and country.

Table 2. Z" Score (Altman et al., 1995; Altman and Hotchkiss, 2006)

\begin{tabular}{|l|l|}
\hline \multicolumn{2}{|l|}{ Z' Score (Altman et al. 1995, p. 3) } \\
\hline $\begin{array}{l}\text { Coefficie } \\
\text { nt }\end{array}$ & Ratio \\
\hline 6.56 & Working Capital / Total Assets \\
\hline 3.26 & Retained Earnings / Total Assets \\
\hline 6.72 & $\begin{array}{l}\text { Operating Profit (EBIT) / Total } \\
\text { Assets }\end{array}$ \\
\hline 1.05 & Book Value Equity / Total Liabilities \\
\hline$Z$ "Score $=6.56 X_{1}+3.26 X_{2}+6.72 X_{3}+1.05 X_{4}$ \\
\hline
\end{tabular}

Source: Our elaboration 


\section{Mll Macrothink}

International Journal of Accounting and Financial Reporting ISSN 2162-3082 2016, Vol. 6, No. 2

The subject of our study is based on unlisted companies that operate in manufacturing industries. For this reason, when considering only the unlisted private limited companies and unlisted public limited companies, either Z' Score or Z" Score can be applied since both models have been adjusted over the years so as to fulfill the adaption to private companies. However, on the basis of the parameters tailored for emerging markets, the Z" Score model needs to be excluded from our analysis due to the fact that Italy is not considered an emerging country. At the end, we apply the Z' Score model (Altman, 1993) since it may be considered more suitable for the Italian context than other versions.

\section{Data Analysis and Method}

The data of this study is extracted from the AIDA databases of Bureau Van Dijk (BvD). This is a commercial database that includes, at the moment of sampling, the financial statements of all the Italian firms, which must deposit their annual accounts. In general terms, the Italian firms that have to authorize their financial statements for publications are all the limited companies ("Società per azioni", "Società a reponsabilità limitata", and "Società in accomandita per azioni"), plus some specific other legal figures such as, for instance, "consorzi" ("consortium") and "imprese sociali" ("social enterprises") ${ }^{\mathrm{iv}}$. AIDA organizes the financial data from administrative sources and filters them into various standard formats in order to ease searching and company comparisons because of their different legal forms.

The statements of income and the statements of financial position of the involved companies were available for an 8-year period preceding the declaration of bankruptcy (referring to the period $2007-2014)^{\mathrm{v}}$.

For statistical sampling, several requirements are set for the empirical data. Firstly, we require that the company to be selected must operate in manufacturing industries. Secondly, the firm has to be instituted as a limited liability company (whereby partnerships and sole proprietors are left out of the study).

Fortunately, the entire period of eight previous years was found for all of the companies analyzed. The sample size is fixed year by year. We consider the 2014 as the year before bankruptcy since they went bankrupted in the first-quarter of 2016 and we assumed that the financial statements of 2015 were not approved. AIDA has seven classes for inactive firms that no longer carry out business activities. We select only firms that are coded as being bankrupt or under receivership; failed firms are coded under the status headings "Bankruptcy" and "Failed for Bankruptcy". These firms generally suffer from serious financial distress.

The sample naturally is composed of companies applying the local accounting requirements; these ones are represented by the civil code requirements (art.2423 -2435-bis), as integrated and interpreted by the Italian local GAAPs, enacted by the "Organismo Italiano di Contabilità" (OIC). This assumption allows us to presume that the financial data is comparable, as determined and presented in compliance with the same, ongoing rules.

The statistical analysis begins with calculating the original Z'-Score for the firms in the data. Following the original model, this Z'Score will be calculated for all sample firms as follows: 
$Z^{\prime}$ Score $=0.717 X_{1}+0.847 X_{2}+3.107 X_{3}+0.420 X_{4}+0.998 X_{5}$

At first, we apply the Z' Score model to the S.p.A. companies that failed in the first quarter of 2016. Secondly, we do the same also for S.r.l. companies ${ }^{\mathrm{vi}}$. The analysis on S.p.A. companies leads to a sample of 87 companies, which declared bankruptcy within the first four months of 2016; the examination of S.r.l. companies leads to a sample of 248 companies who also, declared bankruptcy within the first four months of 2016. Table 3 below indicates the sampling selection process.

Table 3. The sampling selection process

\begin{tabular}{|l|l|}
\hline Country & Italy \\
\hline Period of analysis & $\begin{array}{l}\text { Companies bankrupted in the first quarter of } \\
2016\end{array}$ \\
\hline Legal Form & S.p.A. and S.r.l. \\
\hline Industry Sector & Manufacturing industries \\
\hline $\begin{array}{l}\text { Accounting } \\
\text { requirements }\end{array}$ & Civil code and local GAAPs \\
\hline Sample Coverage & 87 S.p.A. and 248 S.r.1. \\
\hline
\end{tabular}

\section{Empirical Results}

\subsection{Results on S.p.A. Companies}

As far as S.p.A. companies are concerned, the Z' Score was applied and results from manufacturing sectors were analyzed (Table 4).

Table 4. Sample of 87 unlisted manufacturing Italian S.p.A. companies that failed in the 1st quarter of 2016

\begin{tabular}{|c|c|c|c|c|c|c|c|}
\hline \multirow{3}{*}{$\begin{array}{l}\begin{array}{l}\text { Years' before } \\
\text { bankruptcy }\end{array} \\
\text { Year-1 (2014) }\end{array}$} & \multicolumn{7}{|c|}{$\begin{array}{l}\text { Z' Score for "bankrupted" unlisted manufacturing S.p.A. } \\
\text { companies }\end{array}$} \\
\hline & \multicolumn{2}{|c|}{$\begin{array}{l}\text { Distress Area } \\
\left(Z^{\prime}<1.23\right)\end{array}$} & \multicolumn{2}{|c|}{$\begin{array}{ll}\text { Grey } & \text { Area } \\
\left(1.23<Z^{\prime}<2.90\right) & \end{array}$} & \multicolumn{3}{|c|}{$\begin{array}{l}\text { Safe Area } \\
\left(Z^{\prime}>\mathbf{2 . 9 0}\right)\end{array}$} \\
\hline & 81 & $93.10 \%$ & 5 & $5.75 \%$ & 1 & $1.15 \%$ & \\
\hline
\end{tabular}




\begin{tabular}{|l|l|l|l|l|l|l|}
\hline Year-2 (2013) & 72 & $82.76 \%$ & 12 & $13.79 \%$ & 3 & $3.45 \%$ \\
\hline Year-3 (2012) & 69 & $79.31 \%$ & 16 & $18.39 \%$ & 2 & $2.30 \%$ \\
\hline Year-4 (2011) & 62 & $71.26 \%$ & 23 & $26.44 \%$ & 2 & $2.30 \%$ \\
\hline Year-5 (2010) & 58 & $66.67 \%$ & 24 & $27.59 \%$ & 5 & $5.75 \%$ \\
\hline Year-6 (2009) & 58 & $66.67 \%$ & 24 & $27.59 \%$ & 5 & $5.75 \%$ \\
\hline Year-7 (2008) & 52 & $59.77 \%$ & 29 & $33.33 \%$ & 6 & $6.90 \%$ \\
\hline Year-8 (2007) & 40 & $45.98 \%$ & 40 & $45.98 \%$ & 7 & $8.05 \%$ \\
\hline
\end{tabular}

The average aggregate value for each area is representative of classifications made in the above Table, which necessitates comment. Given that in year x-1 (2014), the year before the declaration of bankruptcy, $93.1 \%$ of the companies were classified in the distress zone; the years before show lower percentages $(82.76 \%)$, which are significant and indicate the appropriateness of the classification given. Notice that only one of 87 companies is in the safe area in 2014. The broadness of the grey area constantly reduces year to year from $45.98 \%$ in 2007 to $5.75 \%$ in 2014. Note that the data for S.p.A. companies refers to just 87 companies: although the sample is really too small to be meaningful, the results confirm a good prediction of Z' Score.

\subsubsection{Robustness check on S.p.A. companies}

Prior literature has not only discussed the theme of using the appropriate model for the insolvency prediction, but also the size of the sample on which to verify the effectiveness of the models. On this specific point of assessing the effectiveness through control samples of active companies (summarized in the Appendix A), the main sources of recent literature are cited (Jackson \& Wood; 2013; Christidis \& Gregory, 2010; Altman et al., 2010; Alfaro et al., 2008; Agarwal \& Taffler; 2007; Altman \& Sabato, 2007; Beaver et al., 2005; Shumway; 1999).

In order to make a robustness check, we selected a sample of unlisted manufacturing companies active in 2016 and, as we made for bankrupted companies, we compute the Z' Score for a sample of 9,129 companies in order to check its applicability to the Italian manufacturing industry. The percentage of failed S.p.A. companies compared on the total number of companies analysed is $0.95 \%$.

Table 5: Random sample of 9,129 unlisted manufacturing Italian S.p.A. companies "active" in the 1 st quarter of 2016

Z' Score for "active" unlisted manufacturing S.p.A. companies 


\begin{tabular}{|c|c|c|c|c|c|c|}
\hline & \multicolumn{2}{|c|}{$\begin{array}{l}\text { Distress } \\
\left(Z^{\prime}<\mathbf{1 . 2 3}\right)\end{array}$} & \multicolumn{2}{|c|}{$\begin{array}{ll}\text { Grey } & \text { Area } \\
\left(1.23<Z^{\prime}<2.90\right) & \end{array}$} & \multicolumn{2}{|c|}{$\begin{array}{l}\text { Safe Area } \\
\left(Z^{\prime \prime}>2.90\right)\end{array}$} \\
\hline Year-1 (2014) & 2,679 & $29.35 \%$ & 5,154 & $56.46 \%$ & 1,296 & $14.20 \%$ \\
\hline Year-2 (2013) & 2,755 & $30.18 \%$ & 5,156 & $56.48 \%$ & 1,218 & $13.34 \%$ \\
\hline Year-3 (2012) & 2,933 & $32.13 \%$ & 5,059 & $55.42 \%$ & 1,137 & $12.45 \%$ \\
\hline Year-4 (2011) & 2,711 & $29.70 \%$ & 5,222 & $57.20 \%$ & 1,196 & $13.10 \%$ \\
\hline Year-5 (2010) & 2,759 & $30.22 \%$ & 5,310 & $58.17 \%$ & 1,060 & $11.61 \%$ \\
\hline Year-6 (2009) & 3,035 & $33.25 \%$ & 5,031 & $55.11 \%$ & 1,063 & $11.64 \%$ \\
\hline Year-7 (2008) & 2,243 & $24.57 \%$ & 5,582 & $61.15 \%$ & 1,304 & $14.28 \%$ \\
\hline Year-8 (2007) & 1,919 & $21.02 \%$ & 5,886 & $64.48 \%$ & 1,324 & $14.50 \%$ \\
\hline
\end{tabular}

As a comparison, it is estimated the $\mathrm{Z}$ ' Score of healthy companies in the control sample. The analysis has shown that the majority of companies are placed in the area of uncertainty (grey). On average the $60 \%$ of the classifications fall into that grey area and only the $13 \%$ on average of Italian companies control sample had characteristics to be categorized as "healthy".

\subsection{Results on S.r.l. companies}

By switching the analysis on the S.r.l. companies, the situation is different, as shown in the Table below (Table 6).

Table 6: Sample of 248 manufacturing Italian S.r.l. failed in the 1st quarter of 2016

\begin{tabular}{|c|c|c|c|c|c|c|}
\hline \multirow{3}{*}{$\begin{array}{l}\begin{array}{l}\text { Years' before } \\
\text { bankruptcy }\end{array} \\
\text { Year-1 (2014) }\end{array}$} & \multicolumn{6}{|c|}{ Z' Score for "bankrupted" manufacturing S.r.l. companies } \\
\hline & \multicolumn{2}{|c|}{$\begin{array}{l}\text { Distress } \\
\left(Z^{\prime}<\mathbf{1 . 2 3}\right)\end{array}$} & \multicolumn{2}{|c|}{$\begin{array}{l}\text { Grey } \quad \text { Area } \\
\left(1.23<Z^{\prime}<2.90\right)\end{array}$} & \multicolumn{2}{|c|}{$\begin{array}{l}\text { Safe Area } \\
\left(Z^{\prime}>2.90\right)\end{array}$} \\
\hline & 203 & $81.85 \%$ & 31 & $12.50 \%$ & 14 & $5.65 \%$ \\
\hline Year-2 (2013) & 99 & $39.92 \%$ & 121 & $48.79 \%$ & 28 & $11.29 \%$ \\
\hline
\end{tabular}




\begin{tabular}{|l|l|l|l|l|l|l|}
\hline Year-3 (2012) & 89 & $35.89 \%$ & 127 & $51.21 \%$ & 32 & $12.90 \%$ \\
\hline Year-4 (2011) & 86 & $34.68 \%$ & 126 & $50.81 \%$ & 36 & $14.52 \%$ \\
\hline Year-5 (2010) & 86 & $34.68 \%$ & 123 & $49.60 \%$ & 39 & $15.73 \%$ \\
\hline Year-6 (2009) & 81 & $32.66 \%$ & 135 & $54.44 \%$ & 32 & $12.90 \%$ \\
\hline Year-7 (2008) & 54 & $21.77 \%$ & 162 & $65.32 \%$ & 32 & $12.90 \%$ \\
\hline Year-8 (2007) & 53 & $21.37 \%$ & 166 & $66.94 \%$ & 29 & $11.69 \%$ \\
\hline
\end{tabular}

The sample of 248 S.r.l. companies shows a great effectiveness of prediction exclusively in the year before bankruptcy, with 203 out of 248 companies falling in the "Distress Area" $(81.85 \%)$. The years before show lower percentages which are always less than $50 \%$ and indicate the need of a more appropriate model for the classification: the average $\%$ of distress companies is $31.57 \%$ from 2007 to 2013.

\subsubsection{Robustness check on S.r.l. companies}

As we made in the previous analysis, we use a control sample of 26,040 S.r.l companies. The percentage of failed S.r.l. companies compared on the total number of companies analysed is $0.95 \%$.

Table 7: Random sample of 26,040 unlisted manufacturing Italian S.r.l. companies active in the 1 st quarter of 2016

\begin{tabular}{|c|c|c|c|c|c|c|}
\hline \multirow[b]{3}{*}{ Year-1 (2014) } & \multicolumn{6}{|c|}{ Z' Score for "active" manufacturing S.r.l. companies } \\
\hline & \multicolumn{2}{|c|}{$\begin{array}{l}\text { Distress Area } \\
\left(Z^{\prime}<1.23\right)\end{array}$} & \multicolumn{2}{|c|}{$\begin{array}{l}\text { Grey } \quad \text { Area } \\
\left(1.23<Z^{\prime}<2.90\right)\end{array}$} & \multicolumn{2}{|c|}{$\begin{array}{l}\text { Safe } \\
\left(Z^{\prime}>2.90\right)\end{array}$} \\
\hline & 5,422 & $20.82 \%$ & 16,607 & $63.77 \%$ & 4,011 & $15.40 \%$ \\
\hline Year-2 (2013) & 6,080 & $23.35 \%$ & 16,243 & $62.38 \%$ & 3,717 & $14.27 \%$ \\
\hline Year-3 (2012) & 6,250 & $24.00 \%$ & 16,290 & $62.56 \%$ & 3,500 & $13.44 \%$ \\
\hline Year-4 (2011) & 5,837 & $22.42 \%$ & 16,889 & $64.86 \%$ & 3,314 & $12.73 \%$ \\
\hline Year-5 (2010) & 6,145 & $23.60 \%$ & 17,052 & $65.48 \%$ & 2,843 & $10.92 \%$ \\
\hline
\end{tabular}




\begin{tabular}{|l|l|l|l|l|l|l|}
\hline Year-6 (2009) & 6,691 & $25.70 \%$ & 16,588 & $63.70 \%$ & 2,761 & $10.60 \%$ \\
\hline Year-7 (2008) & 4,446 & $17.07 \%$ & 18,085 & $69.45 \%$ & 3,509 & $13.48 \%$ \\
\hline Year-8 (2007) & 3,945 & $15.15 \%$ & 18,546 & $71.22 \%$ & 3,549 & $13.63 \%$ \\
\hline
\end{tabular}

As we made for S.p.A., it is estimated the Z' Score of "healthy" S.r.l. companies in the control sample. The analysis indicates that the majority of companies are placed in the area of uncertainty (grey). On average the $65 \%$ of the observations fall into the grey area and only the $13 \%$ on average of the control sample had characteristics to be considered "healthy".

\subsection{Comments on Results}

The model applied to S.p.A. and S.r.l. companies produces very different results and could lead to divergent conclusions. An explanation of the discrepancies presented could be found in the provided models of governance. S.p.A. companies can decide among three models:

- the Traditional model, composed of a board of directors and a board of auditors;

- the German model, composed of a board of directors and a supervisory board; and

- the Anglo-saxon model, consisting of a board of directors and an internal audit committee.

That said, S.p.A. companies that opt for the traditional model - that is the most used one must be monitored by a "collegio sindacale" ("board of auditors") and audited by an auditor or audit firm. When the S.p.A. companies do not meet specific requirements, the audit can be effected by the "collegio sindacale"; in this circumstance, the members of the board must be enrolled in the national register of auditors.

At the time the research is substantially contextualized, S.r.l. companies need to be audited only when they satisfy, at least, one of the specific criteria, such as:

I. the company has a social capital at least equivalent to the minimum required for S.p.A.;

II. the company has to present consolidated financial statements;

III. controls a company which must be audited; or

IV. exceeds the definition provided for small companies for two periods (or the first existing period).

It should be specified that the decree 91/2014 (converted into law 116/2014) eliminated the first criterion.

According to this, one may suppose that the lack of control could substantiate in a less reliable financial reporting, even if the produced data does not separately address audited and 


\section{Mll Macrothink}

International Journal of Accounting and Financial Reporting ISSN 2162-3082 2016, Vol. 6, No. 2

non-audited data. This is especially true when the date of the declared bankruptcy is farther in advance. This may, to some extent, make one consider that the data is adjusted when the distress status becomes irreversible.

Another potential explanation consists in the qualitative consideration that S.r.l. companies usually present lower accounting values than S.p.A. companies. This might imply that a negative period could determine a sudden financial or economic crisis. However, this consideration does not seem to be aligned with the current development of the crisis; if this was true, many S.r.l. companies should have fallen in a more drastic way in the 2008-2011 period (the hardest crisis period). This hypothesis has not been verified.

\section{Conclusions and Limitations}

In this study we examined unlisted manufacturing companies of large (S.p.A.) and medium size (S.r.l.). The two samples of failed companies are 87 S.p.a. and 248 S.r.l. which declared bankruptcy from 1st Jan to 31st Mar of 2016. In light of the above results, the application of Altman's Z-Score to the context of Italian manufacturing leads to several interesting conclusions: applying the score to the sample of bankrupted S.p.A., the companies classified in the distress zone are on average $78.62 \%$ in the previous five years before failure. This demonstrates a great power of the $Z$ ' Score to predict financial distress, given that the percentage of companies in the "distress area" increases year by year. On the contrary, the analysis applied to the S.r.l. companies brings us to a different conclusion: with the exception of the year before failure $(81.85 \%)$, all the other years present a percentage of companies included in the "distress area" below $50 \%$. In this case, the Z' Score is not able to precisely predict crisis. We also set two control samples of active companies (S.r.l. and S.p.A.) in order to test the effectiveness of the model.

Although the study is reliable, an important limitation should be taken into consideration when it comes to applying the research findings. The prediction of Altman's bankruptcy model depends on Z' Score values lower than 1.23, in between 1.23 and 2.90, and higher than 2.90. Since the findings depend on Z' Score values, this could make the research findings less reliable because they are strongly linked to Z' Scores and, thus, the model offers little flexibility. The study carried out shows the need to reformulate parameters and add others based upon the peculiarities of Italian companies which are constituted by low capitalization, massive use of credit by banking institutions, and accounting policies which at times are not transparent (Altman et al., 2013). At the same time, we may state with a great conviction that such a model can be extremely helpful to investors, regulators, and even political decision makers.

This study assumes that significant variables in the functioning of the Z-score model are the facts that the company is monitored and that the accounting data is audited. This conclusion is in line with other professional research applied in a pre-crisis period (CNDC/Aristeia, 2007). This conclusion may find a limit in the production of the S.r.l. data, which does not distinguish between audited and non-audited companies.

Our samples do not allow us to study the effects of industry or country on the risk of failure. 


\section{Ml Macrothink}

International Journal of Accounting and Financial Reporting

ISSN 2162-3082

2016, Vol. 6, No. 2

Larger sample across different sectors and countries would remedy this shortcoming. Further improvement of our analysis would be attained by using more frequent data such as monthly or quarterly instead of yearly. Since Z-Score shows increased sensitivity to equity based measures, further incorporation of the "market" would add to models' explanatory power (e.g. it would be possible to proxy market value of Total Assets by measuring its equity component at market value (total market assets $=$ market equity + book liabilities)).

\section{References}

Agarwal, V., \& Taffler, R. J. (2007). Twenty-five years of the Taffler z-score model: Does it really have predictive ability?. Accounting and Business Research, 37, 285-300.

Aharony, J., Jones, C. P., \& Swary I. (1980). An analysis of risk and return characteristics of corporate bankruptcy using capital market data. The Journal of Finance, 35, 1001-1016.

Alberici, A. (1975). Analisi dei Bilanci e Previsione delle Insolvenze, ISEDI, Milano.

Alfaro, E., García, N., Gámez, M., \& Elizondo, D. (2008). Bankruptcy forecasting: An empirical comparison of AdaBoost and neural networks. Decision Support Systems, 45, 110122.

Aliakbari, S. (2009). Prediction of corporate bankruptcy for the UK firms in manufacturing industry. Brunel University.

Altman, E. I. (1968). Financial ratios, discriminant analysis and the prediction of corporate bankruptcy. The Journal of Finance, 23, 589-609.

Altman, E. I., Haldeman, R. G., \& Narayanan, P. (1977). Zeta analysis. Journal of Banking and Finance, 1, 29-54.

Altman, E. I. (1984). The success of business failure prediction models: an international survey. Journal of Banking and Finance, 8, 171-198.

Altman, E.I. (1993). Corporate Financial Distress and Bankruptcy: A complete Guide to predicting and avoiding distress and profiting from bankruptcy. New York, Wiley \& Sons.

Altman, E.I., Hartzell, J., \& Peck, M. (1995). Emerging Markets Corporate Bonds: A Scoring System. New York, Salomon Brothers Inc.

Altman, E.I. (2005). An emerging market credit scoring system for corporate bonds. Emerging Market Review, 6, 311-323.

Altman, E.I., \& Hotchkiss, E. (2006). Corporate Financial Distress \& Bankruptcy. 3rd edition, New Jersey, Wiley \& Sons.

Altman, E. I., \& Sabato, G. (2007). Modelling Credit Risk for SMEs: Evidence from the U.S. Market. Journal Accounting, Finance and Business Studies, 43, 332-357

Altman, E. I., Sabato, G., \& Wilson, N. (2010). The value of non-financial information in 
small and mediumsized enterprise risk management. The Journal of Credit Risk, 6, 1-33.

Altman, E.I., Danovi, A. \& Falini, A. (2013). Z-Score models' application to Italian companies subject to extraordinary administration. Bancaria, 4, 24-37.

Appetiti, S. (1984). L’Utilizzo dell'Analisi Discriminatoria per la Previsione delle Insolvenze: Ipotesi e Test per un'Analisi Dinamica. Servizio Studi della Banca d'Italia. Temi di Discussione, Roma.

Argenti, J. (1976). Corporate Collapse: The Causes and Symptoms. McGraw-Hill.

Balwind, J., \& Glezen, G. (1992). Bankruptcy Prediction Using Quarterly Financial Statement Data. Journal of Accounting, Auditing \& Finance, 3, 269-285.

Beaver, W.H. (1966). Financial Ratios As Predictors of Failure. Journal of Accounting Research, 4, 71-111.

Beaver, W. H., McNichols, M., Rhie, J. (2005). Management of the loss reserve accrual and the distribution of earnings in the property-casualty insurance industry. Review of Accounting Studies, 10, 93-122.

Bellovary, J.L., Giacomino, D.E., \& Akers, M.D. (2007). A review of bankruptcy prediction studies: 1930 to present. Journal of Financial Education, 33.

Bijnen, E.J., \& Wijn, M.F.C.M. (1994). Corporate Prediction Models. Ratios or Regression Analysis?. Faculty of Economics of Tilburg University.

Charitou, A., Neophytou. S., \& Charalambous, C. (2004). Predicting corporate failure: empirical evidence for the UK. European Accounting Review, 13, 465-497.

CNDC/Aristeia, Fallimenti e collegio sindacale (2007). Available at: http://www.fondazionenazionalecommercialisti.it/system/files/imce/areetematiche/ari/Fallime nti_ottobre2007.pdf.

Christidis, C.Y., Gregory, A. (2010). Some New Models for Financial Distress Prediction in the UK. Centre for Finance and Investment, Discussion Paper no: 10/04.

Daubie, M., \& Meskens, N. (2002). Business failure prediction: a review and analysis of the literature. New trends in Banking Management, 71-86.

Deakin, E. (1972). A discriminant analysis of predictors of business failure. Journal of Accounting Research, 10, 167-179.

Flagg, J., Giroux, G., \& Wiggins, C. (1991). Predicting Corporate Bankruptcy Using Failing Firms. Review of Financial Economics, 1, 67-78.

Forestieri, G. (1986). La previsione delle insolvenze aziendali: profili teorici e analisi empiriche. Giuffrè Editore, Milano.

Giacosa, E., Mazzoleni, A., Teodori, C., \& Veneziani, M. (2015). Insolvency prediction models: an empirical study in Italy. SIDREA Conference 2015, Pisa, Italy. 


\section{Macrothink}

International Journal of Accounting and Financial Reporting

ISSN 2162-3082

2016, Vol. 6, No. 2

Hillegeist, S., Cram, D., Keating, E., \& Lundstedt, K. (2004). Assessing the Probability of Bankruptcy. Review of Accounting Studies, 9, 5-34.

Hill, N.T., Perry, S.E., \& Andes, S. (1996). Evaluating firms in financial distress: an event history analysis. Journal of Applied Business Research, 12, 60-71.

Huang, S.M., Tsai, C.F., Yen, D.C., \& Cheng, Y.L. (2008). A hybrid financial analysis model for business failure prediction. Expert systems with application, 35, 1034-1040.

Jackson, R., Wood, A. (2013). The performance of insolvency prediction and credit risk models in the UK: A comparative study. The British Accounting Review, 45, 183-202.

Johnsen, T., \& Melicher, R. (1994). Predicting corporate bankruptcy and financial distress: information value added by multinomial logit models. Journal of Economics and Business, 46, 269-286.

Keasey, K., McGuinness, P., \& Short, H. (1990). Multilogit approach to predicting corporate failure - further analysis and the issue of signal consistency. Omega, 18, 85-94.

Keasey, K., \& Watson, R. (1991). Financial distress models: a review of their usefulness. British journal of Management, 2, 89-102.

Laitinen, E. K. (1994). Traditional versus operating cash flow in failure prediction. Journal of Business Finance and Accounting, 21, 215-228.

Lennox, C.S. (1999). The accuracy and incremental information content of audit reports in predicting bankruptcy. Journal of Business, Finance and Accounting, 26, 757-778.

Ohlson, J. (1980). Financial ratios and the probabilistic prediction of bankruptcy. Journal of Accounting Research, 18, 109-131.

Platt, H. D., Platt, M. B., \& Pedersen, J. G. (1994). Bankruptcy discriminant with real variables. Journal of Business Finance and Accounting, 21, 491-509.

Platt, H.D., and Platt, M.B. (2002). Predicting corporate financial distress: reflections on choice-based sample bias. Journal of Economics and Finance, 26, 184-199.

Ramser, J.R. \& Foster, L.O. (1931). A Demonstration of Ratio Analysis. Bureau of Business Research Bulletin n.40, University of Illinois.

Shumway, T. (1999). Forecasting bankruptcy more accurately: A simple hazard model. University of Michigan: Available on the internet at http://wwwpersonal.umich.edu/ shumway/papers.dir/forcbank.pdfSmith, F.R. (1930). A Test Analysis of Unsuccessful Industry Companies. Bureau of Business Research, n. 31, University of Illinois.

Taffler, R.J., \& Agarwal V. (2003). Do statistical failure prediction models work ex ante or only ex post?. Deloitte \& Touche Lecture Series on credit risk, University of Antwerp (Belgium).

Wall, A. (1936). How to evaluate financial statements. Harper, New York. 


\section{Ml Macrothink}

International Journal of Accounting and Financial Reporting ISSN 2162-3082 2016, Vol. 6, No. 2

Ward, T.J., \& Foster, B.P. (1997). A note on selecting a response measure for financial distress. Journal of Business Finance and Accounting, 24, 869-879.

Wilcox, J.W. (1976). The Gambler's Ruin Approach to Business Risk. Sloan Management Review, 33-46.

Winakor, A., \& Smith, R. (1935). Changes in the financial structure of unsuccessful industrial corporations. bulletin n. 51. Bureau of Business Research, University of Illinois, Urbana, Ill .

Wu W.W. (2010). Beyond business failure prediction. Expert systems with application, 37, 2371-2376.

\section{Appendix}

Appendix 1. Sample size of previous studies on insolvency prediction. Source: our elaboration from Giacosa et al. (2016).

\begin{tabular}{|l|l|l|l|l|}
\hline Authors & $\begin{array}{l}\text { Time Period of } \\
\text { Sample analysis }\end{array}$ & No. Failed & $\begin{array}{l}\text { No. Non- } \\
\text { failed }\end{array}$ & $\begin{array}{l}\text { Bankruptcy } \\
\text { rate }\end{array}$ \\
\hline Jackson \& Wood (2013) & $2000-2009$ & 101 & 6,494 & $1.53 \%$ \\
\hline $\begin{array}{l}\text { Christidis \& Gregory } \\
(2010)\end{array}$ & $1978-2006$ & 589 & 49,063 & $1.19 \%$ \\
\hline $\begin{array}{l}\text { Altman, Sabato \& Wilson } \\
(2010)\end{array}$ & $2000-2007$ & 66,833 & $5,749,188$ & $1.15 \%$ \\
\hline $\begin{array}{l}\text { Alfaro, Garzia \& } \\
\text { Elizondo (2008) }\end{array}$ & $2000-2003$ & 590 & 590 & $50 \%$ \\
\hline Agarwal \& Taffler (2007) & $1980-2005$ & 232 & 27,011 & $0.85 \%$ \\
\hline $\begin{array}{l}\text { Altman \& Sabato (2007) } \\
1994-2002\end{array}$ & $1962-2002$ & 544 & 74,823 & $0.72 \%$ \\
\hline $\begin{array}{l}\text { Beaver, McNichols \& } \\
\text { Rhie (2005) }\end{array}$ & $1962-1992$ & 300 & 28,226 & $1.05 \%$ \\
\hline \begin{tabular}{l} 
Shumway (1999) \\
\hline
\end{tabular} & 120 & $5.97 \%$ \\
\hline
\end{tabular}




\section{Macrothink}

International Journal of Accounting and Financial Reporting

ISSN 2162-3082 2016, Vol. 6, No. 2

\footnotetext{
i In 2013, Altman, Danovi and Falini provided a long list of authors. Some of them are: Tamari, 1966; Beaver, 1966; Altman, 1968; Deakin, 1972; Alberici, 1975; Altman et. al., 1977, 1993; Wilcox, 1976; Argenti, 1976; Ohlson, 1980; Appetiti, 1984; Forestieri, 1986; Baldwin and Glezen, 1992; Flagg, Giroux and Wiggins, 1991; Bijnen and Wijn, 1994; Shumway, 1999; Hillegeist, et. al., 2004).

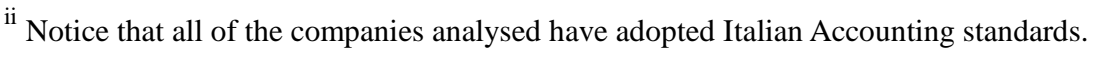

iii 11,451 citations according to Google Scholar as of June 16th 2016.

iv Italian companies have to approve their financial statements within 120 days after the end of the period. In some specific cases, the deadline is postponed by another 60 days, so that the approval can be effected within 180 days after the end of the period. Companies have to deposit their annual accounts to the official register within 30 days of approval.
}

$\checkmark$ All the companies selected have had at least 10 years of history. Although Z-Score analysis previous applications refers to the five years before bankruptcy, we decide to extend the period of analysis to 8 years in order to assess a longer period.

${ }^{v i}$ The numbers indicated in the samples of S.p.A.s and S.r.l.s exclusively regarded firms for whom we collected the financial data necessary to carry out the Z' Score analysis. Regarding the lengthy period, the AIDA database allows us to gather data for periods no longer than 8 years preceding the date that the analysis was elaborated.

\section{Copyright Disclaimer}

Copyright for this article is retained by the author(s), with first publication rights granted to the journal.

This is an open-access article distributed under the terms and conditions of the Creative Commons Attribution license (http://creativecommons.org/licenses/by/3.0/). 